\title{
Language and Literacy: Issues and Considerations
}

\author{
Maria C. Hartman ${ }^{(}$, Onudeah D. Nicolarakis and Ye Wang * \\ Teachers College, Columbia University, 525 W. 120th St. Box 223, New York, NY 10027, USA \\ * Correspondence: yw2195@tc.columbia.edu
}

Received: 22 May 2019; Accepted: 10 July 2019; Published: 12 July 2019

\begin{abstract}
This article provides background on the major perspectives involving the development of English language and literacy with respect to the evolving demography of d/Deaf and hard-of-hearing children and adolescents. It synthesizes research and controversies on the developmental similarity hypothesis - that is, whether the acquisition of English language and literacy of d/Deaf and hard-of-hearing students is developmentally similar to that of typical language/literacy learners. The outcomes of this discussion have instructional implications and proffer guidelines for teacher preparation programs. The article concludes with directions for further research.
\end{abstract}

Keywords: language; literacy; deafness; developmental similarity hypothesis

\section{Introduction}

Guided by the developmental similarity hypothesis or qualitative similarity hypothesis [1-3], this article surveys the most up-to-date research related to language and literacy development of individuals who are $\mathrm{d} /$ Deaf or hard of hearing (d/Dhh). The lower case use of "deaf" as an identifier is based on auditory levels; whereas, there is a community composed of members that identify themselves culturally "Deaf", born to Deaf parents and/or use sign language to primarily communicate. In this article, "d/Dhh" represents the deaf, hard of hearing and Deaf communities. Throughout, we concur with Mayer [4] that in order to become competent readers and writers, $d / D h h$ learners are not different from their hearing counterparts in regard to what skills they need to acquire and master, because the process of learning to read or write is fundamentally the same or similar across populations. The development of a face-to-face form of a language-be it spoken or signed —is essential in learning to read and write, as is phonological awareness and knowledge of the language to be read. The question is not what skills children need to learn to read, but rather HOW individuals who are $\mathrm{d} / \mathrm{Dhh}$ acquire and master these skills, and at what rate. While maintaining the perspective that developing print literacy requires access to the sublexical components of the language to be read, and is most beneficially acquired during early childhood when the brain is primed for this type of input, we also recognize the value and seek to understand the uniqueness as well as advantages of how some d/Dhh individuals successfully develop language and literacy skills (e.g., [5]).

This article begins with an investigation of the evolving demography of individuals who are d/Dhh. Then, it moves on to discuss the language and literacy (i.e., reading and writing) development of individuals who are $\mathrm{d} / \mathrm{Dhh}$ using a parallel structure of introducing the development in general first, and then specifically addressing the research and controversies for the $\mathrm{d} / \mathrm{Dhh}$ population. Reading development is discussed in greater detail, because it currently receives the most attention from the field. The article concludes with implications and suggestions for research and practice. Throughout, it is our intention to throw a brick to attract jade - that is, to start a discussion to attract more ideas. Therefore, our review is not exhaustive; for a more comprehensive review on the issues, please refer to other publications within this issue. 


\section{The Evolving Demography}

This section provides a descriptive account of the English language and literacy development of children and adolescents who are $\mathrm{d} / \mathrm{Dhh}$ over the last two decades. Throughout this period, there have been major shifts in technology, policy, and service provision that have influenced the language and literacy learning trajectories of many of these children, even as some of the demographics of the field have remained fairly stable. It continues that approximately two to three out of every 1000 children in the United States are born with a detectable level of permanent hearing loss in one or both ears, and close to $95 \%$ percent of those children are born to hearing parents [6]. Fifteen percent of all American school-age children (aged between 6 and 19) have some degree of permanent or transient hearing loss, and more than half of those children have what is termed an educationally significant hearing loss in that it affects how they learn and influences academic achievement [6]. $\mathrm{d} / \mathrm{Dhh}$ children are ethnically and socioeconomically diverse, although children of low-income families remain at a disproportionate risk for hearing-related disabilities [7]. The population of children with hearing loss has become increasingly diverse in terms of concurrent disabilities, as the number of children born at very early gestational ages are now surviving, but presenting with complex needs in addition to their hearing loss. It is now reported that $40 \%$ to $50 \%$ of the children who were deaf or hard of hearing have additional disabilities $[7,8]$.

Currently, almost $98 \%$ of all babies born in the United States are screened for hearing loss, as opposed to fewer than 3\% in the early 1990s [9]. The establishment of universal newborn hearing screening, new screening technologies, as well as procedures for assessing hearing in newborns, has led to a reduction in the average age of hearing loss identification to the age of six months in 2007 from 30 months just two decades ago [9]. This timely identification of hearing loss in infants provides the opportunity for earlier access to visual or spoken language, hearing assistive technology, and early intervention services. Although some challenges in state tracking systems remain, particularly those related to failures to follow up from referrals to audiologic evaluations, over 5000 infants are identified very early in life each year [9].

Along with early identification, techniques for fitting amplification on newborns continue to improve. Digital hearing aids, cochlear implants, and remote microphone systems provide better access to higher quality sound at younger ages than ever before. Infants can be fit with hearing aids during the first weeks of life, and research has evidenced that when children with severe to profound hearing loss begin using hearing assistive technology between six and 18 months of age, listening, language, and speech development improve $[10,11]$. Early intervention services have also become available for increasing numbers of children between birth and age three. These services, funded through Part C of the Individuals With Disabilities Education Act (IDEA), provide family-centered intervention, which includes counseling, parent education, and services to support early signed and/or spoken communication development $[12,13]$. Substantial work remains in the area of counseling and reliability associated with early intervention services for caregivers and their $\mathrm{d} / \mathrm{Dhh}$ children, but the services do much to meet the unique family support that is required. This shift in policy and practice has changed the demographics of the deaf population entering the educational system. Currently, $85 \%$ of all $\mathrm{d} / \mathrm{Dhh}$ students in the United States are educated in public school programs, with $43 \%$ spending most of the school day in general education classrooms [14]. Most of these students receive support from an itinerant teacher of $\mathrm{d} / \mathrm{Dhh}$ and/or an educational interpreter. Others spend part of their school day in the general education classroom, and the remainder in resource room settings receiving instruction from a teacher of $\mathrm{d} / \mathrm{Dhh}$.

All of these events have inspired an optimism that $\mathrm{d} / \mathrm{Dhh}$ students might attain language and literacy levels closer to those of their typical peers, and this has occurred in many instances [15-17], yet many others continue to struggle. In regards to communication options, there continues to be debate around whether deaf children should learn sign language, a sign system, or use listening to learn spoken language [18-20]. Gravel and O'Gara [19] as well as Fitzpatrick et al. [21] stressed in their work that at the current time, there is no solid evidence that one communication option is 
optimal for all young children who are $\mathrm{d} / \mathrm{Dhh}$, and that regardless of the mode chosen, language development is dependent on regular, consistent, and accessible input. d/Dhh children of deaf parents, with access to a natural sign language from birth, and those who have greater access to spoken language generally demonstrate somewhat better academic outcomes than d/Dhh children without those characteristics. Nevertheless, neither group as a whole achieves at the level of their hearing age peers [22-25]. This situation affects not only language development but also cognitive development, knowledge of the world, and social functioning, all of which influence each other cumulatively over time [26].

\section{Language Development}

\subsection{Language Development in General}

The acquisition of language is one of the most remarkable achievements of early childhood, and the literature on child language development has found that the quality and quantity of early language input is associated with children's language performance and later with academic achievement [27]. For any child, the first 12 months of life include decisive experiences for language acquisition. Those with auditory access learn to parse the speech signal, map spoken words to referents, and discover syntactic patterns as they co-construct a communication foundation with their caregivers. Deaf children of signing deaf parents are similarly mapping signs to referents, and by 12 months are producing their first sign or word. By 18 to 24 months, signing and speaking children who have access to a natural language are linking two signs or words to form simple sentences and show early command of the word order patterns of their native language [28]. Later language developmental milestones (from two to four years of age) further evidence a strikingly similar order of progression [29]. By age five, hearing children essentially master the sound system and grammar of their language and acquire a vocabulary of thousands of words. Rinaldi et al. [30] found similar patterns of vocabulary acquisition in the deaf children of deaf signing parents.

\subsection{Research and Controversies on Language Development of the d/Dhh}

"Being deaf is not the cause of delays in language development; rather, the delays are the direct manifestations of a social world in which language is not fully accessible and thus largely incomprehensible" [31] (p. 77). For the $95 \%$ of d/Dhh babies born to hearing parents [32], early critical experiences with language input are initially absent. Currently, a robust amount of research has revealed a significant divide in the language outcomes of children who have full access to language, signed or spoken, during the first 12 months, and those who begin experiencing language later. In general, compared to hearing children, $\mathrm{d} / \mathrm{Dhh}$ children who are late to language exposure take longer to learn their first 50 words, longer to form combinations [33], and have less vocabulary knowledge [34]. These children also experience delays in the acquisition and use of grammatical structures in spoken language and writing [35,36], have less developed narrative skills [37], and struggle to achieve age-appropriate reading levels [24].

Empirical research on the development of sign language by d/Dhh children with either deaf or hearing parents is limited and varied in focus, and has mostly been used to attempt to explain constructs such as executive function and theory of mind. In a study of signing deaf children's development of executive function, Botting, Jones, and Marshall [38] found that although some deaf children perform within the normal range, particularly those with deaf parents, as a group, deaf children scored below hearing peers on the majority of executive function tasks; they suggested that language delay may be associated with their findings. Kelly et al. [39] found that signing d/Dhh children of non-signing hearing parents were delayed in identifying lies and sincere false statements when matched for chronological age, but that deaf children who experienced early access to conversations with their deaf parents demonstrated no delay in theory of mind activities. Findings suggested that limited access to linguistic exchanges delayed the development of key pragmatic skills. A number of studies [40-42] explored 
the development of sign language as a functional tool in children with additional disabilities such as autism, cerebral palsy, and/or developmental delay. Cupples et al. [43] found that d/Dhh children with additional disabilities show specific patterns of development that were influenced by the type, severity, and nature of the secondary disability. They offer that the type of additional disability could be used to understand delays in language development in the population of $\mathrm{d} / \mathrm{Dhh}$ children with additional disabilities when a formal assessment of cognitive ability was not feasible.

Among the increasing number of children receiving cochlear implants, most research produced from the early 2000s and into the early 2010s noted a high degree of variability in the outcomes of children who are d/Dhh. Although some children did achieve age-appropriate listening and spoken language abilities, many continued to show significant deficits. Geers, Tobey, Moog, and Brenner [24] evaluated the listening and spoken language outcomes of 181 children who were eight to nine years old and who had received a cochlear implant prior to five years of age. They reported that only $30 \%$ of the children had developed language comprehension abilities comparable with those of their peers with typical hearing. In addition, Incerti, Ching, and Cowan [44] evaluated the listening and spoken language outcomes of 451 children who were three years old and who were diagnosed with hearing loss and received auditory intervention between birth and age three. Similar to Geers et al. [24], Incerti et al. found that some children with hearing loss achieved language abilities that were similar to those of children with typical hearing. On average, though, these children's expressive and receptive language and speech production were below the level attained by children with normal hearing at three years old. Some studies reported vocabulary outcomes within the normal range of typically hearing children [45-47], while others found the opposite [48,49]. Yet other studies indicated that complicated language components, such as morphosyntax and pragmatic aspects, remained the most difficult to acquire [24,50].

At the moment, a lot of attention is being directed at the information coming out of the Longitudinal Outcomes of Children with Hearing Impairment (LOCHI) study [51] in Australia. The LOCHI study is a population-based longitudinal study that prospectively evaluates the development of a group of Australian children with hearing loss as they progress in age. This study is unique in that it includes all children in Australia whose hearing loss was diagnosed through either Universal Newborn Hearing Screening (UNHS) or standard care $(\mathrm{N}=460)$; all of the children had access to the same post-diagnostic services provided by the national audiological service provider, Australian Hearing. This system provides a nationwide ability to compare results regardless of when and where the children's hearing loss was discovered. The information gathered includes standardized assessments of children's speech and spoken language skills, literacy and numeracy skills, academic achievement, psychosocial development, and cognition. At each test interval, demographic information is collected regarding the child, the child's family, and the intervention that the child receives.

The LOCHI study provides comprehensive data for examining the relationships between different outcomes and predictors, and incorporates randomized controlled trials of hearing aid prescription and cochlear implantation. When assessed at five years of age, the children in the study whose hearing loss was discovered at birth and who received early intervention had better spoken language abilities than those whose hearing loss was discovered later [51]. On average, children fitted with hearing aids before six months of age had higher language scores than those fitted later. For children with severe or profound hearing loss, those who received a cochlear implant before 12 months of age had significantly higher language scores than those who received a cochlear implant at an older age. They also noted that in that same group of later implanted children, many had marked deficits in pre-reading skills compared to their typical hearing peers. Dettman et al. [52] and Geers et al. [24] have reported similar findings.

While there is consensus that early identification and early provision and fitting of assistive listening devices (ALDs) can provide better access to spoken language, a decisive factor in language outcomes for d/Dhh children appears to be related to consistency and the amount of device use. Moeller and Tomblin [53] suggested a dose-response relationship where better language skills are 
associated with an increased duration and consistency of use of ALDs. Walker et al. [54] found that for children with mild hearing loss, full-time hearing aid (HA) users (users who wore HAs an average of 8.7 hours per day) demonstrated significantly higher scores on vocabulary and grammar measures compared with part-time users (users who wore HAs between two and 8.7 hours per day) and nonusers. Additionally, Tomblin et al. [55] noted that high devise use (10 hours or more per day) was associated with better language outcomes regardless of severity of hearing loss. Although their research has shown a correlation between ALD use and language progress, Munoz, Preston and Hicken [56] found that parents often didn't understand the importance of consistent use or overestimated their child's hearing devise use time. They offer that more support from audiologists, Early Intervention (EI) providers, and Speech Language Pathologists (SLPs) is needed to help caregivers overcome challenges in effective ADL management for their child.

\subsection{Summary}

Collectively, the language trajectories of individual children who are d/Dhh vary significantly and are associated with multiple variables. These variables include access to early identification, quality of intervention, hearing assistive device use, and audiological management. $d / D h h$ children develop language in a similar manner to that of typically hearing children, provided that they are in a language-rich environment, whether signed or spoken. This occurs most readily for d/Dhh children of signing deaf parents, who constitute approximately $5 \%$ of the deaf population. For $\mathrm{d} / \mathrm{Dhh}$ children of hearing parents, language development will depend on the age at which they are exposed to a perceptually accessible first language, as well as the quality of the input of that language. This language diversity or difference contributes to or 'cascades' into other social, emotional, and cognitive risks as well as all language-related areas of development, most particularly literacy.

\section{Literacy Development}

This section begins by describing the multifaceted nature of reading. It goes on to review the Simple View of Reading as a formula through which we can understand the various components of successful reading as well as how they interact. Finally, we define and differentiate the notions of constrained and unconstrained skills and contextualize their significance within the Simple View of Reading.

\subsection{Reading Development in General}

As one of the most researched areas in education, reading is also heatedly debated. Recognizing the danger of deconstructing reading into isolated components, we echo the perspectives of the RAND Reading Study Group [57] and Snow [58] in which decoding, fluency, vocabulary, motivation, prior knowledge, self-regulation, and interest all interact in nonlinear, unequal ways during the complex process of reading [59]. Therefore, reading is a process involving at least four elements: reader (e.g., prior knowledge, motivations), text (e.g., complexity, familiarity), activity or task (e.g., locate details, evaluate arguments), and situation or context (e.g., during high-stakes testing, working in cooperative groups, reading for pleasure). Reading comprehension emerges from the interaction of an individual (reader) engaged with linguistic materials (text) for a given or self-generated purpose (activity) in a specific time and place (situation) [60].

Admitting that the Simple View of Reading [61] does not fully explain all the factors mentioned (e.g., text and task), we use it as a window into the factors contributing the most to reading. The Simple View states that proficient reading consists of two key components: word recognition and language comprehension. The word recognition component includes efficient decoding, precise sight-word identification, fluent word reading, and access to semantic information in the reader's mental lexicon. In this way, efficient word recognition allows the reader to quickly pronounce words while also triggering the recognition of words acquired through language experiences. Linguistic comprehension encompasses knowledge of facts and concepts, vocabulary, language and text structures, verbal 
reasoning structures, and strategies. The interaction of these two components results in reading comprehension. Successful reading is an act of recognizing words that are written and having the ability to comprehend the meaning behind what was read. Word recognition or decoding has an interdependent relationship with language comprehension. One cannot "read" without the other.

For developmental considerations in reading assessment, the Simple View is often translated into the differentiation between constrained and unconstrained reading skills. For novice readers, constrained skills (e.g., print concepts, letter knowledge, phonemic awareness, phonics) involve learning a finite set of items, which while requiring practice, can be mastered within a relatively short period of time. These skills are critical as novice readers begin to negotiate text, but alone are not sufficient for comprehension. Unconstrained skills (e.g., vocabulary and language comprehension) develop more slowly over a reader's lifetime through experience and as one engages with more complex reading [62-64]. As unconstrained skills grow and expand, they have more and more influence on reading comprehension. Different understandings/perspectives on the roles of constrained and unconstrained skills in reading often leads to the controversies in the reading research for individuals who are d/Dhh.

\subsection{Research and Controversies on Reading Development of the d/Dhh}

This section describes the role of phonology in word recognition, which is the first component of the Simple View of Reading. It cites research exploring the potential role of phonological processing for $\mathrm{d} / \mathrm{Dhh}$ readers as well as some alternative word recognition strategies for $\mathrm{d} / \mathrm{Dhh}$ readers who use sign language as a primary mode of communication. Next, it explores the second area of the Simple View: language comprehension in reading. A brief review of affective factors as well as the potential effect of hearing assistive technology follows. Finally, we include a summary of the section as a whole.

\subsubsection{Phonological Processing in Word Recognition}

Most hearing readers encode print by sounding words out phonetically. This encoding allows a reader to hold chunks of text in short-term memory long enough for higher-level processors to assign meaning to it for overall comprehension. Since phonological processing plays a fundamental role in reading acquisition for hearing readers, researchers have investigated whether and how deaf readers are able to activate phonological representations when reading, and there has been considerable variability within the literature. In a meta-analysis, Mayberry, Del Giudice, and Lieberman [65] analyzed 57 studies exploring this question, and reported that about half of them provided evidence in favor of phonological coding and awareness skills in severely and profoundly deaf participants. They concluded that phonological coding and awareness skills were a low to moderate predictor of reading achievement for deaf individuals, while overall language ability played a more significant role on reading development.

Harris and Moreno [66], as well as Luetke-Stahlman and Nielsen [67], found that more proficient deaf readers used more phonology than less proficient deaf readers. Kyle and Harris $[17,68,69]$ in three different studies also showed that some deaf readers access phonological processing, although usually to a lesser degree than hearing readers. Spencer and Tomblin [70] reported phonological awareness to be predicative of reading abilities in cochlear implant users. In a longitudinal study of children in Australia who used cochlear implants and digital hearing aids, Ching, Day, and Cupples [71], as well as Cupples et al. [72], found that phonological awareness was a significant predictor of reading at age five, after controlling for receptive vocabulary and nonverbal cognitive ability. A number of more recent studies [73,74] have also suggested phonological skills as the key to reading for young children who are $\mathrm{d} / \mathrm{Dhh}$. As testament to the primacy of the role of phonology in learning to read, various interventions have been designed to facilitate the auditory access to English phonology through visual means for d/Dhh students. These include cued speech (see the review in [75]), visual phonics (see the review in [76]), and speechreading (see the review in $[17,69])$. 
Eye movement studies on foveal and parafoveal word processing in reading are also contributing to our understanding of the reading process in deaf readers. These studies show that when a word in a text is fixated, identities of letters and their corresponding phonemes are activated early during the fixation. Blythe et al. [77] reported on two experiments in which participants' eye movements were recorded as they silently read sentences containing correctly spelled words (e.g., church), pseudohomophones (e.g., cherch), and spelling controls (e.g., charch). Three groups were tested: teenagers with permanent childhood hearing loss (PCHL), chronological age-matched controls, and reading age-matched controls. These researchers found that the teenagers with PCHL showed a pseudohomophone advantage from both directly fixated words and parafoveal preview, which was similar to their hearing peers. They suggest that this data provides strong evidence for phonological recoding during silent reading in teenagers with PCHL.

Alternately, other studies have not shown clear use of phonological processing in deaf readers [78-81]. As a result, some researchers believe phonology might be bypassed by focusing on morphemes in the orthography of text. According to Gaustad [82], orthographic processing, or the visual processing of whole words or parts of words, may be a viable approach to decoding for deaf readers. The proposed morphographic approach to word identification with its emphasis on morphographic elements replaces an emphasis on phonemic elements as the focal element for analyzing print. This has implications for classroom practice; however, Gaustad noted that morphographic processing has not been extensively researched, particularly in relation to deaf participants.

Furthermore, McQuarrie and Parrila [83] suggested that bilingual d/Dhh readers had a different approach to cracking the orthographic code for reading. The authors believed that focusing on a sign language phonological system would support the development of reading acquisition. Rather than concentrating on how signed languages can be directly mapped to print, this shift in thinking or approach to research could then explore how dual languages interact/work in bilingual minds cognitively. The authors recognized that while there were universal fundamental reading skills that needed to be developed for all readers, the HOW question might mean a qualitatively different development for $\mathrm{d} / \mathrm{Dhh}$ readers.

Meanwhile, Allen et al. [84] agreed with the validity of the qualitative similarity hypothesis regarding the role of phonology in reading. However, they suggested a visual sign phonology instead of a sound-based English phonology as consequential for d/Dhh readers. In a review of research on the impact of early visual language exposure on a variety of developmental outcomes, including literacy, cognition, and social adjustment, they came to the conclusion that young deaf children of signing parents were able to recognize language patterns in segmented sign streams, which is a skill that is critical for early reading acquisition. They hypothesized that this skill would allow the brain and its memory processes to retain more words and facilitate the reading process. By having a visual sign phonology foundation, $\mathrm{d} / \mathrm{Dhh}$ children would be able to map the sign phonological unit to print, especially during early emergent literacy (e.g., ABC letter writing or letter shape recognition). Allen et al. also found that American Sign Language (ASL) exposure had an independent effect on the participants' letter knowledge and print concepts. An analysis of a parent rating scale given to over 100 children in this study showed that $\mathrm{d} / \mathrm{Dhh}$ children from $\mathrm{d} / \mathrm{Dhh}$ signing parents were more likely to demonstrate language and reading skills, whereas the results for $\mathrm{d} / \mathrm{Dhh}$ children from hearing parents varied based on signing ability. Collectively, the authors supported the qualitative similarity hypothesis only if it was modality independent. Other studies $[85,86]$ have also proposed using ASL phonology to teach reading, although the impact of ASL phonology knowledge on English reading is still questionable [87].

\subsubsection{Language Comprehension in Reading}

Language comprehension is a top-down, higher-level process that extracts explicit and implicit information from text and integrates text-based information with prior/world knowledge and knowledge of the structure of English (e.g., morphology, syntax, semantics, and pragmatics) [88]. 
Unfortunately, the research on improving language outcomes for school-age children who are $\mathrm{d} / \mathrm{Dhh}$ is limited, and offers little advice to education practitioners. For instance, in a review of literature on classroom language interventions with children who are d/Dhh, Easterbrooks, Cannon, and Trussell [89] reviewed various interventions available to teachers of $\mathrm{d} / \mathrm{Dhh}$ children, but found none with strong evidence of success for an individual language structure. They suggested that a more wide ranging research agenda was necessary.

Another salient language-related factor is metacognition, that is, thinking about thinking, which refers to being aware of one's reading comprehension and ways to improve it. Readers must use metacognitive strategies to monitor levels of text difficulty, evaluate the relevance of background knowledge, identify problems in comprehension, process meaningful text, and set/reach reading goals [90]. The National Reading Panel [91] found that explicit comprehension strategy instruction was as effective as vocabulary and text comprehension instruction, with success rates of $85 \%$ to $90 \%$ measured by outcomes among experimental groups. For students who are d/Dhh, very few studies have examined their metacognitive skills, and the available data often suggest difficulties in this area [92,93]. However, research on skilled deaf readers suggested that they were able to use metacognitive strategies as proficiently as their hearing peers, and that the competent use of metacognitive strategies distinguished skilled deaf readers from non-skilled deaf readers $[5,94,95]$.

Meanwhile, what is often overlooked in reading research for the $\mathrm{d} / \mathrm{Dhh}$ is affective elements such as interest, engagement, or self-efficacy. Dewey [96] argued that interest-based learning was naturally superior to effort-based learning. While motivation, generally speaking, is a reader factor, interest is typically situated within a specific context. Springer, Dole, and Hacker [97] stated: "affective elements impact individuals' willingness to focus attention or to use cognitive reading strategies, and individuals' use of these strategies impacts their enjoyment of the task. These affective and cognitive factors, in turn, influence text comprehension" (pp. 529-530). Research on the affective factors in reading for students who are d/Dhh is limited. In an interview study with 29 prelingually deaf adolescents, Strassman [98] found that very few participants defined reading as meaningful, while most referred to grades instead of comprehension as indicators of good reading skills. In her review of literature, Strassman [99] suggested that many deaf readers took a passive approach to reading because they were not taught or encouraged to become independent readers. Poor reading comprehension leads to low interest or motivation to read, which results in less reading practice and further decrease in reading comprehension. Without instructional intervention or motivational encouragement, the circle goes on.

\subsubsection{Additional Consideration: Hearing Assistive Technology}

As hearing assistive technology has become more sophisticated, some researchers [100-102] believe that comprehending the auditory phonological structure of words is a key component that is necessary in deaf children's early literacy education. This has led to numerous investigations of children with cochlear implants. A long-term study by Geers et al. [24] found that phonological coding ability and linguistic competence were both predictive skills for reading in elementary school. However, in a follow-up study of those same participants in high school, age-appropriate reading achievement had not been maintained for the majority of students. The authors suggested that the gap between deaf children and hearing peers widens with age. Marschark, Rhoten, and Fabich [103] also found deaf children with cochlear implants to be reading at or near grade level during the elementary school years, but high school and college implant users were no longer associated with better reading achievement.

In a longitudinal study to explore whether outcomes had improved in line with earlier diagnosis and better hearing aid technology, Harris, Terlektsi, and Kyle [104] found that recently evaluated d/Dhh elementary school children had an average English vocabulary age that was two years higher than that of children assessed 10 years ago; however, the commensurate improvements did not occur in either phonological awareness or reading ability. They concluded that the advent of better hearing aid technology has not yet enabled d/Dhh children to read at an age-appropriate level. 
In a more recent study, Mayer and Trezek [105] examined the available peer-reviewed research regarding literacy achievement in deaf children with cochlear implants. They looked at 21 studies published between 1996-2016 that collectively reported literacy outcomes for over 1000 children who used cochlear implants. They noted that in terms of reading comprehension, even though there was a wide range of variability, a majority of the participants achieved scores in the average range. Variables that influenced achievement were related to age at implantation and consistency of device use, with earlier implanted children who wore their implants for most of their waking hours scoring better. Another variable was the presence of additional disabilities, where children without additional disabilities had higher scores. The authors note that the sparseness of research in this area is problematic to the field, and they call for more studies that measure the literacy growth of deaf children who use cochlear implants, particularly studies that track development over time.

\subsubsection{Summary of Research and Controversies on Reading Development of the $\mathrm{d} / \mathrm{Dhh}$}

Although there is consensus regarding the skills that are necessary for hearing children's attainment of literacy, there remains considerable debate regarding what skills are important for children who are $\mathrm{d} / \mathrm{Dhh}$, and especially for those whose hearing loss is in the severe to profound range, except for the importance of consistent and high-quality early language, whether signed or spoken. It is important to recognize here that as a population, $\mathrm{d} / \mathrm{Dhh}$ children are a heterogeneous group, and determining the components of reading success for various subgroups is complex. $d / D h h$ children vary, among other things, regarding degree of hearing loss, age of diagnosis, age of provision and use of hearing aid technology, mode of communication, educational setting, and the hearing status of their parents. All of these variables have an impact on literacy $[106,107]$. Another aspect of heterogeneity that must be acknowledged here is the general ability level of $\mathrm{d} / \mathrm{Dhh}$ children with additional needs, such as visual, attention, motor, and learning disabilities. See Edwards [108] for a review of the research on outcomes and grouping studies relative to the nature of the additional disabilities and specific etiologies of deafness. Meanwhile, the advance of assistive hearing technology has brought attention to the field; however, its long-term effect on the reading development of children who are $\mathrm{d} / \mathrm{Dhh}$ is still evolving.

\subsection{Writing Development in General}

Historically, reading and writing were thought to be separate entities within the literacy spectrum, and were taught accordingly [109]. Reading was believed to be a receptive skill that one had to develop in order to understand the author's message, while writing was an expressive and productive skill motivated by the intention of communicating a message to others [110,111]. However, this perspective evolved throughout the 1980s and 1990s as the field began to think more about the writing process than the product. Several studies [112,113] proposed a more interdependent relationship between reading and writing in terms of meta-knowledge (awareness of one's own knowledge) and cognition. More recently, neuroimaging studies have shown that reading and writing activate overlapping brain regions [114], and furthermore, interventions that have focused on a transfer of skills show that reading instruction has a positive effect on writing [115] and writing instruction on reading [116,117].

A conceptual model of writing systems in the brain promoted by Niedo et al. [118] includes four language systems (auditory language perception, visual language perception, oral language production, and manual language production), each of which is multi-leveled (subword, word, multi-word syntax and idioms, and text). These language systems are said to interact with each other and with sensory/motor, cognitive, and attention/executive function systems in the brain. The way the systems interact with each other depends on the developmental level of the writer and the specific language or writing task. As in reading, young children move through a series of stages as they are learning to write. The stages reflect their growing knowledge of the conventions of literacy, letters, sounds, words, and composition. These stages typically begin with drawing and scribbling and the production of mock letters. Letters and letter strings appear next, and then progress into stages where 
invented spelling, phonetic spelling, and conventional spelling successively become more apparent as children move into increasingly more complex composing tasks.

\subsection{Research on Writing Development of the d/Dhh}

Research on the writing of $\mathrm{d} / \mathrm{Dhh}$ students has consistently shown that these individuals demonstrate considerable delays when compared with typically hearing peers [119-121]. Earlier investigations of the writing skills of pre-lingual, severe to profoundly deaf children mainly focused on their limited auditory access to spoken language to note difficulties at the lexical level [122] as well the grammatical level [123]. A later study [124] found much of the same difficulties in hard-of-hearing children who attended school in general education settings. For both groups, noted causes include the lack of or limited exposure to a natural language from birth, the difficulty in accessing and learning English syntactical and morphological structures, either auditorily or visually, and struggles with reading, resulting in limited experience with good writing models. Quality of writing instruction has also been implicated. Maxwell and Falick [125] and Yoshinaga-Itano, Snyder, and Mayberry [126] found that teachers of the $\mathrm{d} / \mathrm{Dhh}$ often focused on teaching basic sentence patterns, which resulted in the production of stilted and overly formulaic writing. More recently, Williams and Mayer [127] in a review of the literature on writing development, instruction, and assessment, for $\mathrm{d} / \mathrm{Dhh}$ three to eight-year-olds published between 1990-2012 found that studies mostly investigated spelling and writing at the word level, and that there was very little information on assessment of writing.

In terms of writing interventions, Strassman and Schirmer's review [121] of the literature of writing interventions for $\mathrm{d} / \mathrm{Dhh}$ students examined 16 studies, with the participants ranging from elementary school students to college students. Only a few writing interventions were considered to have a strong evidence base for practice. This was due to a lack of replication studies and weak methodological designs, which were similar to the issues identified in Trezek and Wang's meta-analysis [76] on reading interventions for students who are d/Dhh. Yet, Strassman and Schirmer [121] did identify a few approaches that seemed promising. One was the collaborative writing approach called Strategic and Interactive Writing Instruction (SIWI), which was described by Wolbers et al. [128-130]. SIWI is an approach to teaching writing that includes explicit and interactive instruction of the writing process and incorporates the learners' knowledge of and linguistic competence from their face-to-face language, which may be ASL or a sign system. Many of its practices are drawn from first and second language acquisition theory.

Schirmer, Bailey, and Fitgerald [131] explored whether a writing assessment rubric could be used as an effective teaching strategy for d/Dhh students who used ASL. In this year-long study, fifth and seventh-grade students were taught to use a rubric that included writing elements such as sequence, story development, organization, word choice, details, sentence structures, and mechanics. Quantitative analysis of compositions written earlier and later in the year showed that the use of the rubric as a teaching strategy significantly improved four traits of writing (topic, content, story development, and organization) for both the fifth and seventh graders. However, the strategy did not improve their performance on text structure, voice/audience, word choice, sentence structures, or mechanics. Easterbrooks and Stoner [132] used a single-subject design to evaluate the use of a visual tool to increase adjective use in the writing of $\mathrm{d} / \mathrm{Dhh}$ adolescents. Students described action pictures using a graphic organizer with guidance from the teachers that faded over time. They found that while adjective use increased the number of action words, story grammar elements decreased.

Berent et al. [133] implemented a visually based focus-on-form approach to writing instruction in which learners were made aware of the grammatical form of language features that they were already able to use communicatively. Experimental groups in this study demonstrated significantly greater improvement in English grammatical knowledge relative to the control group after a 10-week remedial grammar course. In another study, Berent et al. [134] explored the concept of enhanced input in supporting the writing of college age d/Dhh students. Input enhancement (IE) is a model that originated in second language acquisition theory. IE includes techniques used by instructors to make 
salient selected features of a language for students such as word order or parts of words that express tense, agreement, and number. These techniques aim to draw attention to aspects of a language that previously appeared to have made insufficient impact on the learner. Berent et al. found significant improvement immediately after a 10-week instructional intervention, along with retention of skills five months after instruction concluded.

As previously noted, newborn hearing screening programs, early access to language, and advanced hearing assistive technology, including digital hearing aides and cochlear implants, have changed the landscape of deaf education. The literature documents sizable gains in the speech perception and receptive and expressive spoken language, and it was anticipated that improvements in spoken language would also lead to improvements in other language skills such as writing. However, gains in this area have been less remarkable, and reading and writing continue today to be a major challenge for children with cochlear implants. Overall, very few studies have been conducted on deaf children with cochlear implants and their writing development. The following studies review the limited literature available.

Spencer and Marschark [135] evaluated the writing skills of 16 pediatric cochlear implant users and 16 age-matched, normal-hearing children, who were all educated in mainstream classes. Performance measures for the writing analyses included productivity, complexity, and grammaticality measures. On this written language measure, children with cochlear implants performed within one standard deviation of their typical-hearing, age-matched peers on writing accuracy. In addition, children with cochlear implants performed significantly poorer than children with normal hearing on the expressive "Sentence Formulation" subtest. The cochlear implant users also produced fewer words on the written narrative task than did the normal-hearing children, although there was not a significant difference between groups with respect to total words per clause. Furthermore, there was a strong correlation between language performance and total words produced on the written performance measure for children using cochlear implants.

Mayer [136] assessed the writing skills of 33 nine to 16-year-old cochlear implant users, most of whom were educated in mainstream schools and used oral communication in school. Free writing samples showed that $25 \%$ were performing at the expected level for their age, $19 \%$ were performing above average, and $56 \%$ were performing below average. Influences on outcomes included age at implantation, bilateral implantation, and age at testing. Writing outcomes were not as strong as in reading, but did show the use of non-standard English that was typical of d/Dhh children in the past, and the writing samples showed writing strategies such as invented spelling, which is common in hearing children.

Hayes, Kessler, and Treiman [137] also indicated in their study that the spelling skills of the implanted children between six and 12 years of age were comparable to those with typical hearing who were matched for reading abilities. However, when compared to the age-matched children, a significant difference was found between the two groups of children. Children who were cochlear implants users demonstrated lower performance on formulating sentences than their hearing peers, and they were reported to produce fewer words in their expository writing, although no significant difference was noted in terms of total words per clause.

\subsection{Summary}

Learning to write is a complex activity involving spelling, punctuation, and increasingly complex grammar, syntax, and vocabulary. $\mathrm{d} / \mathrm{Dhh}$ children often face the additional challenge of not having a firm foundation in the language or an underdeveloped understanding of the language of the text as they are expected to write it. It would be important to understand more regarding (1) how to develop the language foundation that is needed for learning to write in children who use spoken and/or signed language, including those who are bilingual learners, and (2) the role played by continuing advances in hearing technologies such as digital hearing aids and cochlear implants. 


\section{Recommendations for Future Research}

Regarding recommendations for future research, we advocate for (1) larger descriptive, longitudinal, and correlational studies to examine the interaction of various factors in maximizing the language and literacy development of individuals who are d/Dhh; (2) qualitative designs to compliment information gleaned from student achievement measures; and (3) replication research and intervention studies.

The LOCHI studies mentioned previously in this paper provide an interesting longitudinal research model. In Australia, all the children with hearing loss are followed by Australian Hearing. Australian Hearing is a statutory authority constituted under the Australian Hearing Services Act 1991, which reports to the Minister for Human Services. Australian Hearing provides hearing rehabilitation services and hearing technology to children and adults with hearing loss at no cost to families and conducts hearing-related research via its research division, the National Acoustic Laboratories. All the children receive evidence-based audiology and habilitative services and are monitored carefully over time. Audiology evaluations are consistent and in depth. Hearing aids are fit using prescriptive targets and are monitored to ensure that they are meeting prescribed targets. All the children have regular and complete language, literacy, and social skills evaluations in addition to audiological evaluations. As all the children throughout the country are monitored by the same agency, it is possible to evaluate many aspects of their development, and every child, regardless of communication mode or the presence of additional disabilities is monitored, evaluated, and included in the studies; thus, there is no selection bias in research. The data produced through the LOCHI study is currently being used to explore the impact of newborn hearing screening and early intervention on outcomes of children with hearing loss, as well as the factors that influence these outcomes and possible predictors of these later outcomes.

In the United States (U.S.), the Listening and Spoken Language Data Repository (LSL-DR) [138] was established in 2010 at the Vanderbilt University Medical Center by OPTION Schools, which is an international, non-profit organization comprised of listening and spoken language programs and schools for children who are deaf or hard of hearing in Canada, South America, and the U.S. LSL-DR addresses a critical need for a long-term system-wide outcome data-monitoring program in member schools and programs highlighted in Goal 3b of the 2007 Joint Committee on Infant Hearing position statement supplement [139]. The LSL-DR functions as a multicenter, international data repository for recording and tracking the demographic information and longitudinal outcomes of children with hearing loss who are enrolled in private, specialized programs that focused on supporting listening and spoken language development. Since 2010, annual speech-language-hearing outcomes have been prospectively obtained from 48 programs in four countries for over 5000 children. The design and overview of the project was recently described in a recent American Speech Hearing Association publication [138], and population characteristics and preliminary outcome data have been reported. As the LSL-DR grows, studies will explore the variables that have the greatest impact on enhancing outcomes for children with hearing loss. Residential schools for the d/Deaf might consider a similar type of data collection following the performance of individual students as well as groups of students across schools and programs over time. As with the LSL-DR, this could provide an opportunity for the greater mining of data and possibly contribute to more robust analyses of individual school variables, including curriculum programs.

A major longitudinal effort designed to provide trend data could be complemented by qualitative measures that are designed to capture information on critical transitions experienced by $\mathrm{d} / \mathrm{Dhh}$ students as they proceed through the stages of language and literacy development. The power of using longitudinal data in conjunction with holistic inquiry that is context-specific and acknowledges the uniqueness of individuals and settings can be valuable to improving literacy outcomes for $\mathrm{d} / \mathrm{Dhh}$ students. Qualitative research continues to be of relatively lower visibility in areas of language and literacy education, particularly in deaf education research [140]. Both quantitative and qualitative research models can be important and necessary as we look to develop the fullest understanding of instructional approaches that are most effective for $\mathrm{d} / \mathrm{Dhh}$ students. 
In regards to replication research, a recent study published in Educational Researcher (ER), a peer-reviewed journal of the American Educational Research Association (AERA), reported that although replicating is essential for helping education research improve its usefulness to policymakers and practitioners, less than $1 \%$ of the articles published in the top education research journals are replication studies [141]. The authors note that despite increasing methodological rigor in education research, the field has focused far more on experimental design and far less on replicating important results. The study analyzed the complete publication history of the current 100 education journals with the highest five-year "impact factor" (an indicator of how often a given journal's articles are cited in other scholarly work), finding that only $0.13 \%$ of published articles were replications. More troubling, the study went on to note that of the very small percentage of replication studies in education, replications were significantly less likely to be successful when there was no overlap in authorship between the original and replicating articles. The results emphasize the importance of third-party, direct replications in helping education research improve its ability to shape education policy and practice. While this study did not include the journals where most deaf education research is published, we guess that the results would be similar if these were considered.

Getting research-based instructional practices into the hands of professionals who teach d/Dhh students has been a significant challenge. While encouraging results sometimes emerge in individual intervention studies [76], it has been difficult to successfully bring them to scale and sustain them over an extended period of time in different deaf education settings and under differing conditions. One difficult issue in intervention research is related to the size and heterogeneity of groups in the randomized trials. Groups have to be large enough to detect a significant difference in treatment outcomes when it occurs. In most settings in the field of deaf education, small sample sizes typically render it more difficult to show a statistically significant effect. A meta-analysis conducted by Luckner et al. [101] reviewing 20 literacy intervention studies found that no two studies examined the same dimension of literacy (e.g., vocabulary, reading comprehension, word recognition, writing), and no replications of previous studies had been undertaken. While we acknowledge the difficulties described above, we call for more intervention research in deaf education.

\section{Conclusions}

"Most educators and investigators familiar with the literature in deaf education recognize they can find at least one published study to support almost any methodology or perspective" [32] (p. 518). One of the reasons behind this seeming proliferation of methodologies or perspectives in deaf education is that individuals who are $\mathrm{d} / \mathrm{Dhh}$ are a heterogeneous group with diverse cultural values, family communication choices, learning styles, and child/family needs [142], which leads to a garden variety of practice or viewpoint that might fit one case, but is hard to apply to another. Diversity issues should always be considered when working with individuals who are d/Dhh, and a one-size-fits-all practice is impractical or unrealistic for this population. The idea that students will bring a variety of identities, languages, cultures, and abilities to their learning is a given, and not something educators can control. However, what educators are able to control is their own knowledge base, the implementation of their craft, and their belief system on learning and learners.

Although teachers are considered consumers of research, Kucan, Hapgood, and Palincsar [143] found that $85 \%$ of teachers had no theoretical framework for guiding their teaching of reading or writing. Teacher preparation programs have been slow to close the gap between their pre-service curricula and what the research says regarding teaching reading. Teachers can't teach what they don't know. Teacher preparation programs need to make sure their early childhood and elementary teacher candidates understand how children learn to read, as well as how to help students who struggle with early literacy skills. One big takeaway from the mountains of research that have accumulated over the years is that reading is not a natural act. We are not wired to read from birth [144]. Children become skilled readers by learning that written text is a code for speech sounds, and the primary task for a beginning reader is to crack the code. Even skilled readers rely on decoding. 
Stanislaus Duhaene, a cognitive neuroscientist whose research uses brain imaging to explore the neural basis of reading, has made some claims that from our view support the qualitative similarity hypothesis. From the brain's point of view, he noted that learning to read consists of first recognizing letters and how they combine into written words, and then secondly, connecting them to the brain systems for the coding of speech sounds and meaning. He offered that reading starts in the general visual areas of the occipital pole of the brain, but then very quickly moves into an area that concerns the recognition of the written word. He described the next step as an explosion of activity into at least two brain networks: one that concerns the meaning of the words, and another that concerns the pronunciation and the articulation of the words [145]. Duheane did not study d/Dhh readers, but noted that the work of a beginning reader is to build an interface between the vision and spoken language areas of the brain. He claimed that the brains of all readers are universally structured with the same brain mechanisms, and that reading always requires specialization of the visual system for the shape of letters and connecting them to speech sounds, regardless of the language being read [145].

The premise of the qualitative similarity hypothesis is that all learners, deaf and hearing, learn similarly through similar strategies, but perhaps at different stages or ages, depending on their circumstances and that the acquisition of English by any individual as a first or second language will be developmentally similar, whether they are d/Deaf, hard-of-hearing, or hearing, to others in similar first or second language learning circumstances. Teaching the correspondences between sounds and letters is essential, and is the most efficient way to acquire reading comprehension [2].

Numerous national reports $[57,91]$ have suggested the usefulness of systematic, explicit phonics instruction based on word structure along with wide reading of quality literature for supporting development in early reading instruction. However, other studies have indicated that many in-service teachers are not knowledgeable in the basic concepts of the English language or how to address the basic building blocks of language and reading. One of the reasons for this situation is that many teacher preparation programs that are responsible for training future elementary teachers are not providing sufficient coursework regarding the concepts of literacy pedagogy.

Planning language and literacy instruction and supplemental intervention for $\mathrm{d} / \mathrm{Dhh}$ students whether in a general education classroom, a resource room, or in bilingual education programs begins by assessing the students' current performance, strengths, and needs. Additionally, current functioning must be interpreted in relation to past performance and the nature and quality of instruction that the students have received over time. Another area of need in teacher preparation programs relates to a deeper understanding of and facility with varieties of assessment and assessment tools. Ideally, a framework for documenting students' educational histories, native language and English development, and academic achievement longitudinally would exist allowing teachers, clinicians, and child study teams to differentiate instruction and inform practice. This individualized assessment is particularly relevant in a field where almost half the population experiences one or more additional disabilities.

Accordingly, the curricula in teacher preparation programs in deaf education should include (1) the diversity of individuals who are $\mathrm{d} / \mathrm{Dhh}$, including those with multiple disabilities; (2) understanding of an individual's type and degree of bilingualism or multilingualism; (3) language and literacy development theories, as well as assessment frameworks for consistent progress monitoring; and (4) evidence-based practice in facilitating the language and literacy development of individuals who are $\mathrm{d} / \mathrm{Dhh}$, particularly the strategies in providing rich and varied language experience. Meanwhile, the discussion of language and literacy development for $\mathrm{d} / \mathrm{Dhh}$ continues as more research data is collected and instructional practice evolves.

Author Contributions: conceptualization, M.C.H., Y.W.; writing-original draft preparation, M.C.H., O.D.N.; writing-review and editing, M.C.H., Y.W.

Funding: This research received no external funding.

Conflicts of Interest: The authors declare no conflict of interest. 


\section{References}

1. Andrews, J.F.; Wang, Y. The qualitative similarity hypothesis: Research synthesis and future directions. Am. Ann. Deaf 2015, 159, 468-483. [CrossRef]

2. Paul, P.; Wang, Y.; Williams, C. Deaf Students and the Qualitative similarity Hypothesis: Understanding Language and Literacy Development; Gallaudet University Press: Washington, DC, USA, 2013; ISBN 978-1563685842.

3. Wang, Y.; Andrews, J. Reading and deaf individuals: Perspectives on the qualitative similarity hypothesis. Am. Ann. Deaf 2014, 159, 319-322. [CrossRef] [PubMed]

4. Mayer, C. Addressing diversity in teaching deaf learners to write. In Diversity in Deaf Education; Marschark, M., Lampropoulou, V., Skordilis, E., Eds.; Oxford University Press: New York, NY, USA, 2016; pp. 271-295, ISBN 978-0190493073.

5. Wang, Y.; Silvestri, J.A.; Jahromi, L.B. Selected factors in reading comprehension for deaf and hearing adults: Phonological skills and metacognition. Am. Ann. Deaf 2018, 162, 445-462. [CrossRef] [PubMed]

6. 2016 Annual Data Early Hearing Detection and Intervention [EHDI] Program Summary. Available online: https://www.cdc.gov/ncbddd/hearingloss/ehdi-data2016.html (accessed on 30 April 2019).

7. Guardino, C.; Cannon, J.E. Deafness and diversity: Reflections and directions. Am. Ann. Deaf 2016, 161, 104-112. [CrossRef]

8. Mulla, I.; Harrigan, S.; Gregory, S.; Archbold, S. Children with complex needs and cochlear implants: The parent's perspective. Cochlear Implant. Int. 2013, 14, S38-S41. [CrossRef]

9. White, K.R. Newborn hearing screening. In Handbook of Clinical Audiolgy, 7th ed.; Katz, J., Chasin, M., English, K., Hood, L.J., Tillery, K.L., Eds.; Lippincott Williams \& Wilkins: Baltimore, MD, USA, 2014; pp. 437-458, ISBN 978-1451191639.

10. Lartz, M.N.; Meehan, T. Early Intervention Programs: Therapy Needs of Children Ages 0-3 Years Pre-and Post-cochlear Implantation. In Pediatric Cochlear Implantation; Young, N.M., ILer Kirk, K., Eds.; Springer: New York, NY, USA, 2016; pp. 329-340, ISBN 978-1-4939-2788-3.

11. Yoon, P.J.; Uhler, K. Management of Pediatric Sensorineural Hearing Loss. In Pediatric Sensorineural Hearing Loss: Clinical Diagnosis and Management; Plural Publishing: San Diego, CA, USA, 2017; p. 179.

12. Meinzen-Derr, J.; Wiley, S.; Choo, D.I. Impact of early intervention on expressive and receptive language development among young children with permanent hearing loss. Am. Ann. Deaf 2011, 155, 580-591. [CrossRef] [PubMed]

13. Moeller, M.P. Early intervention and language development in children who are deaf and hard of hearing. Pediatrics 2000, 106, e43. [CrossRef]

14. Digest of Education Statistics: 2016. Available online: https://nces.ed.gov/programs/digest/d16/ch_2.asp (accessed on 30 April 2019).

15. Antia, S.D.; Jones, P.B.; Reed, S.; Kreimeyer, K.H. Academic status and progress of deaf and hard-of-hearing students in general education classrooms. J. Deaf Stud. Deaf Educ. 2009, 14, 293-311. [CrossRef]

16. Fulcher, A.; Purcell, A.A.; Baker, E.; Munro, N. Listen up: Children with early-identified hearing loss achieve age-appropriate speech/language outcomes by 3 years-of-age. Int. J. Pediatr. Otorhinolaryngol. 2012, 76, 1785-1794. [CrossRef]

17. Kyle, F.E.; Harris, M. Predictors of reading development in deaf children: A 3-year longitudinal study. J. Exp. Child Psychol. 2010, 107, 229-243. [CrossRef]

18. Geers, A.E.; Nicholas, J.G. Enduring advantages of early cochlear implantation for spoken language development. J. Speech Lang. Hear. Res. 2013, 56, 643-655. [CrossRef]

19. Gravel, J.S.; O'Gara, J. Communication options for children with hearing loss. Ment. Retard. Dev. Disabil. Res. Rev. 2003, 9, 243-251. [CrossRef] [PubMed]

20. Mellon, N.K.; Niparko, J.K.; Rathmann, C.; Mathur, G.; Humphries, T.; Napoli, D.J.; Handley, T.; Scambler, S.; Lantos, J.D. Should all deaf children learn sign language? Pediatrics 2015, 136, 170-176. [CrossRef] [PubMed]

21. Fitzpatrick, E.M.; Hamel, C.; Stevens, A.; Pratt, M.; Moher, D.; Doucet, S.P.; Neuss, D.; Bernstein, A.; Na, E. Sign language and spoken language for children with hearing loss: A systematic review. Pediatrics 2016, 137, e20151974. [CrossRef] [PubMed]

22. Belzner, K.A.; Seal, B.C. Children with cochlear implants: A review of demographics and communication outcomes. Am. Ann. Deaf 2009, 154, 311-334. [CrossRef] [PubMed] 
23. DeLana, M.; Gentry, A.M.; Andrews, J. The efficacy of ASL/English bilingual education: Considering public schools. Am. Ann. Deaf 2007, 152, 73-87. [CrossRef]

24. Geers, A.; Tobey, E.; Moog, J.; Brenner, C. Long-term outcomes of cochlear implantation in the preschool years: From elementary grades to high school. Int. J. Audiol. 2008, 47, S21-S30. [CrossRef]

25. Wauters, L.N.; Van Bon, W.H.; Tellings, A.E.; van Leeuwe, J.F. In search of factors in deaf and hearing children's reading comprehension. Am. Ann. Deaf 2006, 151, 371-380. [CrossRef]

26. Knoors, H.; Marschark, M. Language planning for the 21st century: Revisiting bilingual language policy for deaf children. J. Deaf Stud. Deaf Educ. 2012, 17, 291-305. [CrossRef]

27. Risley, T.R.; Hart, B. Promoting Early Language Development. In The Crisis in Youth Mental Health: Critical Issues and Effective Programs; Watt, N.F., Ayoub, C., Bradley, R.H., Puma, J.E., LeBoeuf, W.A., Eds.; Praeger Publishers/Greenwood Publishing Group: Westport, CT, USA, 2006; Volume 4, pp. 83-88, ISBN 978-0275984809.

28. Chen Pichler, D. Acquisition. In Sign Language: An International Handbook; Pfau, R., Steinbach, M., Woll, B., Eds.; De Gruyter Mouton: Berlin, Germany, 2012; pp. 647-686, ISBN 978-3110204216.

29. Andrews, J.; Logan, R.; Phelan, J. Milestones of language development. Adv. Speech Lang. Pathol. Audiol. 2008, 18, 16-20.

30. Rinaldi, P.; Caselli, M.C.; Di Renzo, A.; Gulli, T.; Volterra, V. Sign vocabulary in deaf toddlers exposed to sign language since birth. J. Deaf Stud. Deaf Educ. 2014, 19, 303-318. [CrossRef] [PubMed]

31. Kuntze, M.; Golos, D.; Wolbers, K.; O’Brien, C.; Smith, D. School as a site for natural language learning. In Diversity in Deaf Education; Marschark, M., Lampropoulou, V., Skordilis, E.K., Eds.; Oxford University Press: New York, NY, USA, 2016; pp. 77-108, ISBN 978-0-19-049307-3.

32. Marschark, M.; Leigh, G. Recognizing diversity in deaf education: Now what do we do with it?! In Diversity in Deaf Education; Marschark, M., Lampropoulou, V., Skordilis, E.K., Eds.; Oxford University Press: New York, NY, USA, 2016; pp. 1-20, ISBN 978-0-19-049307-3.

33. Nott, P.; Cowan, R.; Brown, P.M.; Wigglesworth, G. Early language development in children with profound hearing loss fitted with a device at a young age: Part I-The time period taken to acquire first words and first word combinations. Ear Hear. 2009, 30, 526-540. [CrossRef] [PubMed]

34. Lund, E.; Douglas, W.M. Teaching vocabulary to preschool children with hearing loss. Except. Child. 2016, 83, 26-41. [CrossRef]

35. Inscoe, J.R.; Odell, A.; Archbold, S.; Nikolopoulos, T. Expressive spoken language development in deaf children with cochlear implants who are beginning formal education. Deaf. Educ. Int. 2009, 11, 39-55. [CrossRef]

36. Spencer, L.J.; Barker, B.A.; Tomblin, J.B. Exploring the language and literacy outcomes of pediatric cochlear implant users. Ear Hear. 2003, 24, 236-247. [CrossRef] [PubMed]

37. Crosson, J.; Geers, A.E. Structural analysis of narratives produced by a group of young cochlear implant users. Ann. Otol. Rhinol. Laryngol. 2000, 109, 118-119. [CrossRef]

38. Botting, N.; Jones, A.; Marshall, C.; Denmark, T.; Atkinson, J.; Morgan, G. Nonverbal executive function is mediated by language: A study of deaf and hearing children. Child Dev. 2017, 88, 1689-1700. [CrossRef] [PubMed]

39. Kelly, C.; Morgan, G.; Freeth, M.; Siegal, M.; Matthews, D. The Understanding of Communicative Intentions in Children with Severe-to-Profound Hearing Loss. J. Deaf Stud. Deaf Educ. 2019, 24, 245-254. [CrossRef]

40. Bruce, S.; Borders, C. Communication and language in learners who are deaf and hard of hearing with disabilities: Theories, research, and practice. Am. Ann. Deaf 2015, 160,368-384. [CrossRef] [PubMed]

41. Herer, G.R. Intellectual disabilities and hearing loss. Commun. Disord. Q. 2012, 33, 252-260. [CrossRef]

42. Knoors, H.; Vervloed, M.P. Educational programming for deaf children with multiple disabilities: Accommodating special needs. In Oxford Handbook of Deaf Studies, Language, and Education; Marschark, M., Spencer, P., Eds.; Oxford University Press: New York, NY, USA, 2003; pp. 82-94, ISBN 978-0195149975.

43. Cupples, L.; Ching, T.Y.C.; Leigh, G.; Martin, L.; Gunnourie, M.; Button, V.; Marnane, S.; Hou, S.; Zhang, V.; Flynn, C.; et al. Language development in deaf or hard-of-hearing children with additional disabilities: Type matters! J. Int. Disabil. Res. 2018, 62, 532-543. [CrossRef] [PubMed]

44. Incerti, P.V.; Ching, T.Y.; Cowan, R. A systematic review of electric-acoustic stimulation: Device fitting ranges, outcomes, and clinical fitting practices. Trends Amplif. 2013, 17, 3-26. [CrossRef] [PubMed] 
45. De Raeve, L.; Vermeulen, A.; Snik, A. Verbal cognition in deaf children using cochlear implants: Effect of unilateral and bilateral stimulation. Audiol. Neurotol. 2015, 20, 261-266. [CrossRef] [PubMed]

46. Sparreboom, M.; Langereis, M.C.; Snik, A.F.; Mylanus, E.A. Long-term outcomes on spatial hearing, speech recognition and receptive vocabulary after sequential bilateral cochlear implantation in children. Res. Dev. Disabil. 2015, 36, 328-337. [CrossRef] [PubMed]

47. Svirsky, M.A.; Teoh, S.W.; Neuburger, H. Development of language and speech perception in congenitally, profoundly deaf children as a function of age at cochlear implantation. Audiol. Neurotol. 2004, 9, 224-233. [CrossRef] [PubMed]

48. Percy-Smith, L.; Busch, G.; Sandahl, M.; Nissen, L.; Josvassen, J.L.; Lange, T.; Rusch, E.; Caye-Thomasen, P. Language understanding and vocabulary of early cochlear implanted children. Int. J. Pediatr. Otorhinolaryngol. 2013, 77, 184-188. [CrossRef] [PubMed]

49. Yoshinaga-Itano, C.; Johnson, C.; Carpenter, K.; Stredler-Brown, A. Outcomes of children with mild bilateral hearing loss and unilateral hearing loss. Semin. Hear. 2008, 29, 196-211. [CrossRef]

50. Van Beijsterveldt, L.M.; Van Hell, J.G. Evaluative expression in deaf children's written narratives. Int. J. Lang. Commun. Disord. 2009, 44, 675-692. [CrossRef]

51. Ching, T.Y.; Dillon, H.; Leigh, G.; Cupples, L. Learning from the Longitudinal Outcomes of Children with Hearing Impairment (LOCHI) study: Summary of 5-year findings and implications. Int. J. Audiol. 2018, 57, S105-S111. [CrossRef]

52. Dettman, S.J.; Dowell, R.C.; Choo, D.; Arnott, W.; Abrahams, Y.; Davis, A.; Dornan, D.; Leigh, J.; Constantinescu, G.; Cowan, R.; et al. Long-term communication outcomes for children receiving cochlear implants younger than 12 months: A multicenter study. Otol. Neurotol. 2016, 37, e82-e95. [CrossRef]

53. Moeller, M.P.; Tomblin, J.B. An introduction to the outcomes of children with hearing loss study. Ear Hear. 2015, 36, 4S-13S. [CrossRef]

54. Walker, E.A.; Holte, L.; McCreery, R.W.; Spratford, M.; Page, T.; Moeller, M.P. The influence of hearing aid use on outcomes of children with mild hearing loss. J. Speech Lang. Hear. Res. 2015, 58, 1611-1625. [CrossRef] [PubMed]

55. Tomblin, J.B.; Harrison, M.; Ambrose, S.E.; Walker, E.A.; Oleson, J.J.; Moeller, M.P. Language outcomes in young children with mild to severe hearing loss. Ear Hear. 2015, 36, 76-91. [CrossRef] [PubMed]

56. Munoz, K.; Preston, E.; Hicken, S. Pediatric hearing aid use: How can audiologists support parents to increase consistency? J. Am. Acad. Audiol. 2014, 25, 380-387. [CrossRef] [PubMed]

57. RAND Reading Study Group. Reading for Understanding: Toward an RED Program in Reading Comprehension, RAND Corporation: Santa Monica, CA, USA, 2002; ISBN 978-0833031051.

58. Snow, C. Assessment of reading comprehension: Researchers and practitioners helping themselves and each other. In Rethinking Reading Comprehension; Sweet, A., Snow, C., Eds.; Guilford Press: New York, NY, USA, 2003; pp. 192-206, ISBN 978-1572308923.

59. Stahl, K.; Garcia, G. Using assessments to map and evaluate the comprehension development of young children. In Handbook of Research on Reading Comprehension, 2nd ed.; Israel, S., Ed.; The Guilford Press: New York, NY, USA, 2017; pp. 241-270, ISBN 978-1-4625-2888-2.

60. Fox, E.; Alexander, P. Text and comprehension: A retrospective, perspective, and prospective. In Handbook of Research on Reading Comprehension, 2nd ed.; Israel, S., Ed.; The Guilford Press: New York, NY, USA, 2017; pp. 335-352, ISBN 978-1-4625-2888-2.

61. Hoover, W.A.; Gough, P.B. The simple view of reading. Read. Writ. 1990, 2, 127-160. [CrossRef]

62. Carpenter, R.; Paris, S. Issues of validity and reliability in early reading achievement. In Children's Reading Comprehension and Assessment; Paris, S., Stahl, S., Eds.; Erlbaum: Mahwah, NJ, USA, 2005; pp. 279-304, ISBN 978-0805846560.

63. Paris, S. Re-interpreting the development of reading skills. Read. Res. Q. 2005, 40, 184-202. [CrossRef]

64. Paris, S.; Luo, S. Confounded statistical analyses hinder interpretation of the NELP report. Educ. Res. 2010, 39, 316-322. [CrossRef]

65. Mayberry, R.I.; Del Giudice, A.A.; Lieberman, A.M. Reading achievement in relation to phonological coding and awareness in deaf readers: A meta-analysis. J. Deaf Stud. Deaf Educ. 2011, 16, 164-188. [CrossRef]

66. Harris, M.; Moreno, C. Speech reading and learning to read: A comparison of 8-year-old profoundly deaf children with good and poor reading ability. J. Deaf Stud. Deaf Educ. 2006, 11, 189-201. [CrossRef] 
67. Luetke-Stahlman, B.; Nielsen, D.C. The contribution of phonological awareness and receptive and expressive English to the reading ability of deaf students with varying degrees of exposure to accurate English. J. Deaf Stud. Deaf Educ. 2003, 8, 464-484. [CrossRef]

68. Kyle, F.E.; Harris, M. Concurrent correlates and predictors of reading and spelling achievement in deaf and hearing school children. J. Deaf Stud. Deaf Educ. 2006, 11, 273-288. [CrossRef] [PubMed]

69. Kyle, F.E.; Harris, M. Longitudinal patterns of emerging literacy in beginning deaf and hearing readers. J. Deaf Stud. Deaf Educ. 2011, 16, 289-304. [CrossRef] [PubMed]

70. Spencer, L.J.; Tomblin, J.B. Evaluating phonological processing skills in children with prelingual deafness who use cochlear implants. J. Deaf Stud. Deaf Educ. 2008, 14, 1-21. [CrossRef] [PubMed]

71. Ching, T.Y.; Day, J.; Cupples, L. Phonological awareness and early reading skills in children with cochlear implants. Cochlear Implant. Int. 2014, 15, S27-S29. [CrossRef] [PubMed]

72. Cupples, L.; Ching, T.Y.; Crowe, K.; Day, J.; Seeto, M. Predictors of early reading skill in 5-year-old children with hearing loss who use spoken language. Read. Res. Q. 2014, 49, 85-104. [CrossRef] [PubMed]

73. Goldberg, H.R.; Lederberg, A.R. Acquisition of the alphabetic principle in deaf and hard-of-hearing preschoolers: The role of phonology in letter-sound learning. Read. Writ. 2015, 28, 509-525. [CrossRef]

74. Nittrouer, S.; Caldwell-Tarr, A.; Sansom, E.; Twersky, J.; Lowenstein, J. Nonword repetition in children with cochlear implants: A potential clinical marker of poor language acquisition. Am. J. Speech Lang. Pathol. 2014, 23, 679-695. [CrossRef] [PubMed]

75. LaSasso, C.; Crain, K.L. Cued language for the development of deaf students' reading comprehension and measured reading comprehension. In Cued Speech and Cued Language for Children Who Are Deaf or Hard of Hearing; LaSasso, C., Crain, K., Leybaert, J., Eds.; Plural Publishing: San Diego, CA, USA, 2010; pp. 285-323, ISBN 978-1597563345.

76. Trezek, B.J.; Wang, Y. Evaluating evidence-based practices in reading interventions for deaf students. In Research in Deaf Education: Contexts, Challenges, and Considerations; Cawthon, S.W., Garberoglio, C.L., Eds.; Oxford University Press: New York, NY, USA, 2017; pp. 277-308, ISBN 978-0190455651.

77. Blythe, H.I.; Dickins, J.H.; Kennedy, C.R.; Liversedge, S.P. Phonological processing during silent reading in teenagers who are deaf/hard of hearing: An eye movement investigation. Dev. Sci. 2018, 21, e12643. [CrossRef] [PubMed]

78. Bélanger, N.N.; Baum, S.R.; Mayberry, R.I. Reading difficulties in adult deaf readers of French: Phonological codes, not guilty! Sci. Stud. Read. 2012, 16, 263-285. [CrossRef]

79. Bélanger, N.N.; Mayberry, R.I.; Rayner, K. Orthographic and phonological preview benefits: Parafoveal processing in skilled and less-skilled deaf readers. Q. J. Exp. Psychol. 2013, 66, 2237-2252. [CrossRef] [PubMed]

80. Emmorey, K.; McCullough, S.; Weisberg, J. The neural underpinnings of reading skill in deaf adults. Br. Lang. 2016, 160, 11-20. [CrossRef] [PubMed]

81. Hirshorn, E.A.; Dye, M.W.; Hauser, P.; Supalla, T.R.; Bavelier, D. The contribution of phonological knowledge, memory, and language background to reading comprehension in deaf populations. Front. Psychol. 2015, 6, 1153. [CrossRef] [PubMed]

82. Gaustad, M.G. Morphographic analysis as a word identification strategy for deaf readers. J. Deaf Stud. Deaf Educ. 2000, 5, 60-80. [CrossRef] [PubMed]

83. McQuarrie, L.; Parrila, R. Literacy and linguistic development in bilingual deaf children: Implications of the "and" for phonological processing. Am. Ann. Deaf 2014, 159, 372-384. [CrossRef] [PubMed]

84. Allen, T.E.; Letteri, A.; Choi, S.H.; Dang, D. Early visual language exposure and emergent literacy in preschool deaf children: Findings from a national longitudinal study. Am. Ann. Deaf 2014, 159, 346-358. [CrossRef] [PubMed]

85. Holmer, E.; Heimann, M.; Rudner, M. Evidence of an association between sign language phonological awareness and word reading in deaf and hard-of-hearing children. Res. Dev. Disabil. 2016, 48, 145-159. [CrossRef] [PubMed]

86. McQuarrie, L.; Abbott, M. Bilingual deaf students' phonological awareness in ASL and reading skills in English. Sign Lang. Stud. 2013, 14, 80-100. [CrossRef]

87. Bochner, J.; Kelstone, A. Phonological knowledge and the development of language and literacy skills in deaf learners. In The Oxford Handbook of Deaf Studies in Language; Marschark, M., Spencer, P., Eds.; Oxford University Press: New York, NY, USA, 2016; pp. 393-406, ISBN 978-0190241414. 
88. Paris, S.; Hamilton, E. The development of children's reading comprehension. In Handbook of Research on Reading Comprehension; Israel, S., Duffy, G., Eds.; Routledge: New York, NY, USA, 2009; pp. 32-53, ISBN 978-0805862010.

89. Easterbrooks, S.; Cannon, J.; Trussell, J. Many languages, one goal: Interventions for language mastery by school-age deaf and hard-of-hearing learners. In Diversity in Deaf Education; Marschark, M., Lampropoulou, V., Skordilis, E., Eds.; Oxford University Press: New York, NY, USA, 2016; pp. 297-323, ISBN 978-0190493073.

90. Ruddell, R.; Unrau, N. Reading as a motivated meaning-construction process: The reader, the text, and the teacher. In Theoretical Models and Processes of Reading, 6th ed.; Alvermann, D., Unrau, N., Ruddell, R., Eds.; International Reading Association: Newark, DE, USA, 2013; pp. 1015-1068, ISBN 978-0872077102.

91. National Reading Panel. Report of the National Reading Panel: Teaching Children to Read: An Evidence-Based Assessment of the Scientific Research Literature on Reading and its Implications for Reading Instruction: Reports of the Subgroups; National Institute of Child Health and Human Development, National Institutes of Health: Washington, DC, USA, 2000; NIH Pub. No. 00-4769.

92. Borgna, G.; Convertino, C.; Marschark, M.; Morrison, C.; Rizzolo, K. Enhancing deaf students' learning from sign language and text: Metacognition, modality, and the effectiveness of content scaffolding. J. Deaf Stud. Deaf Educ. 2011, 16, 79-100. [CrossRef]

93. Schirmer, B.; Bailey, J.; Lockman, A. What verbal protocols reveal about the reading strategies of deaf students: A replication study. Am. Ann. Deaf 2004, 149, 5-16. [CrossRef]

94. Banner, A.; Wang, Y. An analysis of the reading strategies used by adult and student deaf readers. J. Deaf Stud. Deaf Educ. 2011, 16, 2-23. [CrossRef]

95. Silvestri, J.; Wang, Y. A grounded theory of effective reading by profoundly deaf adults. Am. Ann. Deaf 2018, 162, 419-444. [CrossRef] [PubMed]

96. Dewey, J. Democracy in Education; The University of Chicago Press: Chicago, IL, USA, 1903.

97. Springer, S.; Dole, J.; Hacker, D. The role of interest in reading comprehension. In Handbook of Research on Reading Comprehension, 2nd ed.; Israel, S., Ed.; The Guilford Press: New York, NY, USA, 2017; pp. 519-542, ISBN 978-1-4625-2888-2.

98. Strassman, B.K. Deaf adolescents' metacognitive knowledge about school-related reading. Am. Ann. Deaf 1992, 137, 326-330. [CrossRef] [PubMed]

99. Strassman, B.K. Metacognition and reading in children who are deaf: A review of the research. J. Deaf Stud. Deaf Educ. 1997, 2, 140-149. [CrossRef] [PubMed]

100. Geers, A.E.; Hayes, H. Reading, writing, and phonological processing skills of adolescents with 10 or more years of cochlear implant experience. Ear Hear. 2011, 32, 49S-59S. [CrossRef] [PubMed]

101. Luckner, J.L.; Sebald, A.M.; Cooney, J.; Young, J., III; Muir, S.G. An examination of the evidence-based literacy research in deaf education. Am. Ann. Deaf 2005, 150, 443-456. [CrossRef] [PubMed]

102. Paul, P.V.; Wang, Y.; Trezek, B.J.; Luckner, J.L. Phonology is necessary, but not sufficient: A rejoinder. Am. Ann. Deaf 2009, 154, 346-356. [CrossRef] [PubMed]

103. Marschark, M.; Rhoten, C.; Fabich, M. Effects of cochlear implants on children's reading and academic achievement. J. Deaf Stud. Deaf Educ. 2007, 12, 269-282. [CrossRef] [PubMed]

104. Harris, M.; Terlektsi, E.; Kyle, F.E. Literacy outcomes for primary school children who are deaf and hard of hearing: A cohort comparison study. J. Speech Lang. Hear. Res. 2017, 60, 701-711. [CrossRef] [PubMed]

105. Mayer, C.; Trezek, B. Literacy outcomes in deaf students with cochlear implants: Current state of the knowledge. J. Deaf Stud. Deaf Educ. 2018, 23, 1-16. [CrossRef] [PubMed]

106. Lederberg, A.R.; Schick, B.; Spencer, P.E. Language and literacy development of deaf and hard-of-hearing children: Successes and challenges. Dev. Psychol. 2013, 49, 15-30. [CrossRef] [PubMed]

107. Marschark, M.; Harris, M. Success and failure in learning to read: The special case (?) of deaf children. In Reading Comprehension Difficulties: Processes and Intervention; Cornoldi, C., Oakhill, J., Eds.; Lawrence Erlbaum Associates Publishers: Mahwah, HJ, USA, 1996; pp. 279-300, ISBN 978-0805818451.

108. Edwards, L.C. Children with cochlear implants and complex needs: A review of outcome research and psychological practice. J. Deaf Stud. Deaf Educ. 2007, 12, 258-268. [CrossRef] [PubMed]

109. Lee, J.; Schallert, D.L. Exploring the reading-writing connection: A yearlong classroom-based experimental study of middle school students developing literacy in a new language. Read. Res. Q. 2016, 51, 143-164. [CrossRef] 
110. Nelson, N.; Calfee, R.C. The Reading-Writing Connection: Ninety-Seventh Yearbook of the National Society for the Study of Education; University of Chicago Press: Chicago, IL, USA, 1998; ISBN 9780226066363.

111. Tierney, R.J.; Pearson, P.D. Toward a composing model of reading. Lang. Arts 1983, 60, 568-580.

112. Fitzgerald, J.; Shanahan, T. Reading and writing relations and their development. Educ. Psychol. 2000, 35 , 39-50. [CrossRef]

113. Grabe, W.; Kaplan, R.B. Theory and Practice of Writing: An Applied Linguistic Perspective; Longman: New York, NY, USA, 1996; ISBN 978-0582553835.

114. Pugh, K.R.; Frost, S.J.; Sandak, R.; Gillis, M.; Moore, D.; Jenner, A.R.; Mencl, W.E. What does reading have to tell us about writing? Preliminary question and methodological challenges in examining the neurobiological foundations of writing and writing disabilities. In Handbook of Writing Research; MacArthur, C.A., Graham, S., Fitzgerald, J., Eds.; Guilford Press: New York, NY, USA, 2006; pp. 433-448, ISBN 9781593857509.

115. Shanahan, T. Relations among oral language, reading, and writing development. In Handbook of Writing Research; MacArthur, C.A., Graham, S., Fitzgerald, J., Eds.; Guilford Press: New York, NY, USA, 2006; pp. 171-183, ISBN 9781593857509.

116. Weiser, B.; Mathes, P. Using encoding instruction to improve the reading and spelling performance of elementary students at risk for literacy difficulties: A best-evidence synthesis. Rev. Educ. Res. 2011, 81, 170-200. [CrossRef]

117. Graham, S.; Hebert, M. Writing to read: A meta-analysis of the impact of writing and writing instruction on reading. Harv. Educ. Rev. 2011, 81, 710-744. [CrossRef]

118. Niedo, J.; Abbott, R.D.; Berninger, V.W. Predicting levels of reading and writing achievement in typically developing, English-speaking 2nd and 5th graders. Learn. Individ. Differ. 2014, 32, 54-68. [CrossRef]

119. Mayer, C.; Wells, G. Can the linguistic interdependence theory support a bilingual-bicultural model of literacy education for deaf students? J. Deaf Stud. Deaf Educ. 1996, 1, 93-107. [CrossRef]

120. Moores, D.F. Educating the Deaf: Psychology, Principles, and Practices, 5th ed.; Houghton Mifflin: Boston, MA, USA, 2001; ISBN 9780618042890.

121. Strassman, B.K.; Schirmer, B. Teaching writing to deaf students: Does research offer evidence for practice? Remed. Spec. Educ. 2013, 34, 166-179. [CrossRef]

122. Leybaert, J.; Alegría, J. Spelling development in deaf and hearing children: Evidence for use of morpho-phonological regularities in French. Read. Writ. 1995, 7, 89-109. [CrossRef]

123. Conte, M.P.; Rampellie, I.P.; Valterra, V. Deaf children and the construction of written texts. In Children's Early Text Construction; Pontecorvo, C., Orsolini, M., Burge, B., Lawrence, E., Resnick, B., Eds.; Lawrence Earlbaum Associates: Mahwah, NJ, USA, 1996; pp. 303-319, ISBN 9780805815047.

124. Antia, S.D.; Reed, S.; Kreimeyer, K.H. Written language of deaf and hard-of-hearing students in public schools. J. Deaf Stud. Deaf Educ. 2005, 10, 244-255. [CrossRef] [PubMed]

125. Maxwell, M.M.; Falick, T.G. Cohesion \& quality in deaf \& hearing children's written English. Sign Lang. Stud. 1992, 77, 345-372. [CrossRef]

126. Yoshinaga-Itano, C.; Snyder, L.; Mayberry, R. Examining written-language assessment and intervention links to literacy: Can lexical/semantic skills differentiate deaf or hard-of-hearing readers and nonreaders. Volta Rev. 1996, 98, 39-61.

127. Williams, C.; Mayer, C. Writing in young deaf children. Rev. Educ. Res. 2015, 85, 630-666. [CrossRef]

128. Wolbers, K.A. Using balanced and interactive writing instruction to improve the higher order and lower order writing skills of deaf students. J. Deaf Stud. Deaf Educ. 2007, 13, 257-277. [CrossRef] [PubMed]

129. Wolbers, K.A. Strategic and Interactive Writing Instruction (SIWI). Int. J. Appl. Linguist. 2008, 156, $299-326$. [CrossRef]

130. Wolbers, K.A.; Dostal, H.M.; Bowers, L.M. “I was born full deaf.” Written language outcomes after 1 year of strategic and interactive writing instruction. J. Deaf Stud. Deaf Educ. 2011, 17, 19-38. [CrossRef]

131. Schirmer, B.R.; Bailey, J.; Fitzgerald, S.M. Using a writing assessment rubric for writing development of children who are deaf. Except. Child. 1999, 65, 383-397. [CrossRef]

132. Easterbrooks, S.R.; Stoner, M. Using a visual tool to increase adjectives in the written language of students who are deaf or hard of hearing. Commun. Disord. Q. 2006, 27, 95-109. [CrossRef]

133. Berent, G.P.; Kelly, R.R.; Aldersley, S.; Schmitz, K.L.; Khalsa, B.K.; Panara, J.; Keenan, S. Focus-on-form instructional methods promote deaf college students' improvement in English grammar. J. Deaf Stud. Deaf Educ. 2007, 12, 8-24. [CrossRef] 
134. Berent, G.P.; Kelly, R.R.; Porter, J.E.; Fonzi, J. Deaf learners' knowledge of English universal quantifiers. Lang. Learn. 2008, 58, 401-437. [CrossRef]

135. Spencer, P.; Marschark, M. Cochlear implants. In Oxford Handbook of Deaf Studies, Language, and Education; Marschark, M., Spencer, P., Eds.; Oxford University Press: New York, NY, USA, 2003; pp. 434-448, ISBN 978-0195149975.

136. Mayer, C.; Watson, L.; Archbold, S.; Ng, Z.Y.; Mulla, I. Reading and writing skills of deaf pupils with cochlear implants. Deaf. Educ. Int. 2016, 18, 71-86. [CrossRef]

137. Hayes, H.; Kessler, B.; Treiman, R. Spelling of deaf children who use cochlear implants. Sci. Stud. Read. 2011, 15, 522-540. [CrossRef]

138. Bradham, T.; Fonnesbeck, C.; Toll, A.; Hecht, B. The Listening and Spoken Language Data Repository: Design and project overview. Lang. Speech Hear. Serv. Sch. 2018, 49, 108-120. [CrossRef] [PubMed]

139. Supplement to the JCIH 2007 Position Statement: Principles and Guidelines for Early Intervention after Confirmation That a Child Is Deaf or Hard of Hearing. Available online: http://www.jcih.org/JCIH-2007Position-Statement-Supplement.pdf (accessed on 13 May 2019).

140. Nelson, R.L.; Damico, J.S. Qualitative research in literacy acquisition: A framework for investigating reading in children with language impairment. Clin. Linguist. Phon. 2006, 20, 631-639. [CrossRef] [PubMed]

141. Makel, M.; Plucker, J. Facts are more important than novelty: Replication in the education sciences. Educ. Res. 2014, 43, 304-316. [CrossRef]

142. Moeller, M.P.; Ertmer, D.J.; Stoel-Gammon, C. (Eds.) Promoting Language and Literacy in Children who are Deaf or Hard of Hearing; Brookes Publishing: Baltimore, MD, USA, 2016; ISBN 9781598577334.

143. Kucan, L.; Hapgood, S.; Palincsar, A. Teachers' specialized knowledge for supporting student comprehension in text-based discussions. Elem. Sch. J. 2011, 112, 61-82. [CrossRef]

144. Dehaene, S.; Cohen, L. The unique role of the visual word form area in reading. Trends Cogn. Sci. 2011, 15, 254-262. [CrossRef]

145. Dehaene, S. Reading in the Brain: The New Science of How We Read; Penguin Books: New York, NY, USA, 2009; ISBN 978-0143118053.

(C) 2019 by the authors. Licensee MDPI, Basel, Switzerland. This article is an open access article distributed under the terms and conditions of the Creative Commons Attribution (CC BY) license (http://creativecommons.org/licenses/by/4.0/). 